\title{
Review on the Control of Waterborne Diseases - The Islamic Approach
}

\author{
Muhammad Lokman Md Isa, ${ }^{1,2}$, Mohammed Abdullah Jainul ${ }^{3}$, Afzan Mat Yusof ${ }^{1,2}$ \\ ${ }^{1}$ Department of Basic Medical Sciences, Kulliyyah of Nursing, International Islamic University Malaysia (IIUM) \\ Kuantan \\ ${ }^{2}$ IIUM Human Cellular and Molecular Biology Cluster (iMoleC), IIUM Kuantan \\ ${ }^{3}$ Department of Biomedical Science, Kulliyyah of Allied Health Sciences, IIUM Kuantan
}

\begin{abstract}
Introduction: Scarcity of fresh water is currently blighting the population of the least developed countries around the world. According to WHO, waterborne diseases accounts for $4.1 \%$ of total disability adjusted life years (DALYs) with a mortality rate of 1.8 million per year. Numerous pathogens and chemicals may be the potential sources of water contamination that leads to waterborne diseases in humans. Some pathogens are only active and express disease whilst within the host. The aim of this article is to identify the cause of water-borne diseases and how to control it from the Islamic perspective. Material and Methods: In this review we had compiled the latest scientific findings related to waterborne diseases and integrated them with Islamic approach of cleanliness. There are many Hadiths of the Prophet (peace be upon him) (PBUH) regarding methods of cleanliness with scientific background to control waterborne diseases. Water pollution may be a natural process, men made, intentional or accidental. More often than not, man are infected after accidently consuming or coming in contact with contaminated water Results: Scientific literature search reveals that individual hygiene and sanitation is the most prominent way to prevent waterborne diseases. In Islam, Prophet Muhammad (PBUH) puts a great emphasize on purification in terms of personal cleanliness and made it mandatory to follow rule to remain pure both physically and spiritually. Conclusions: Sunnatic approaches of cleanliness may hinder waterborne disease.
\end{abstract}

KEYWORDS: waterborne diseases, Islam, cleanliness, prevention, contamination.

\section{INTRODUCTION}

Pathogens such as viruses, bacteria and parasites commonly use water as a mode of transmission to spread waterborne diseases. ${ }^{1}$ In fact, individuals may be infected directly by drinking water containing pathogens or by utilizing of contaminated water in cooking, washing or even swimming. ${ }^{2}$ The least developing countries are the most vulnerable to contracting waterborne diseases specially diarrhoea. ${ }^{2}$ Although the developed countries are not excluded from the list but the frequency is 5 to 6 times more in the least developing countries. ${ }^{16}$ The number of waterborne disease cases has reduced but it still remains as the primary cause of gastrointestinal (GI) illness. ${ }^{4}$ It is justified that, control of waterborne diseases is all about being clean and maintaining a quality hygiene and sanitation, and at the same time population has to

Corresponding author:

Muhammad Lokman Md Isa

Department of Basic Medical Sciences,

Kulliyyah of Nursing,

IIUM Human Cellular and Molecular Biology Cluster

(iMoleC),

International Islamic University Malaysia,

Jalan Sultan Ahmad Shah, 25200 Kuantan, Pahang

Telephone: +60129645581

Email: lokman@iium.edu.my alert with the latest environment changes. In Islam, personal hygiene is made compulsory for all Muslims based on the Quran and Sunnah.

\section{Global Incidences of Waterborne Diseases}

Waterborne diseases are considered as a single largest threat to global public health. ${ }^{3}$ There are more than 100 pathogenic viruses, bacteria and parasites which are responsible for water contamination. ${ }^{4}$ Though there are not many studies on waterborne disease prevalence, the incidence is high. ${ }^{4}$ Up to $35 \%$ of paediatrics presenting with diarrhoea is caused by rotavirus. Rotavirus is the cause of death for over half a million children each year. ${ }^{5}$ India records the highest annual prevalence of waterborne disease up to 40 million cases amounting to 73 million working days loss equivalent to 600 million USD. ${ }^{6}$

\section{Waterborne Pathogens}

Typically enteric pathogens which are transmitted via faecal-oral route are responsible for waterborne diseases. ${ }^{8}$ Pathogens causing waterborne diseases can be categorized broadly according to Straub and Chandler. ${ }^{9}$ In 2003 as shown in Table 1. 
Table 1 Pathogens causing waterborne diseases

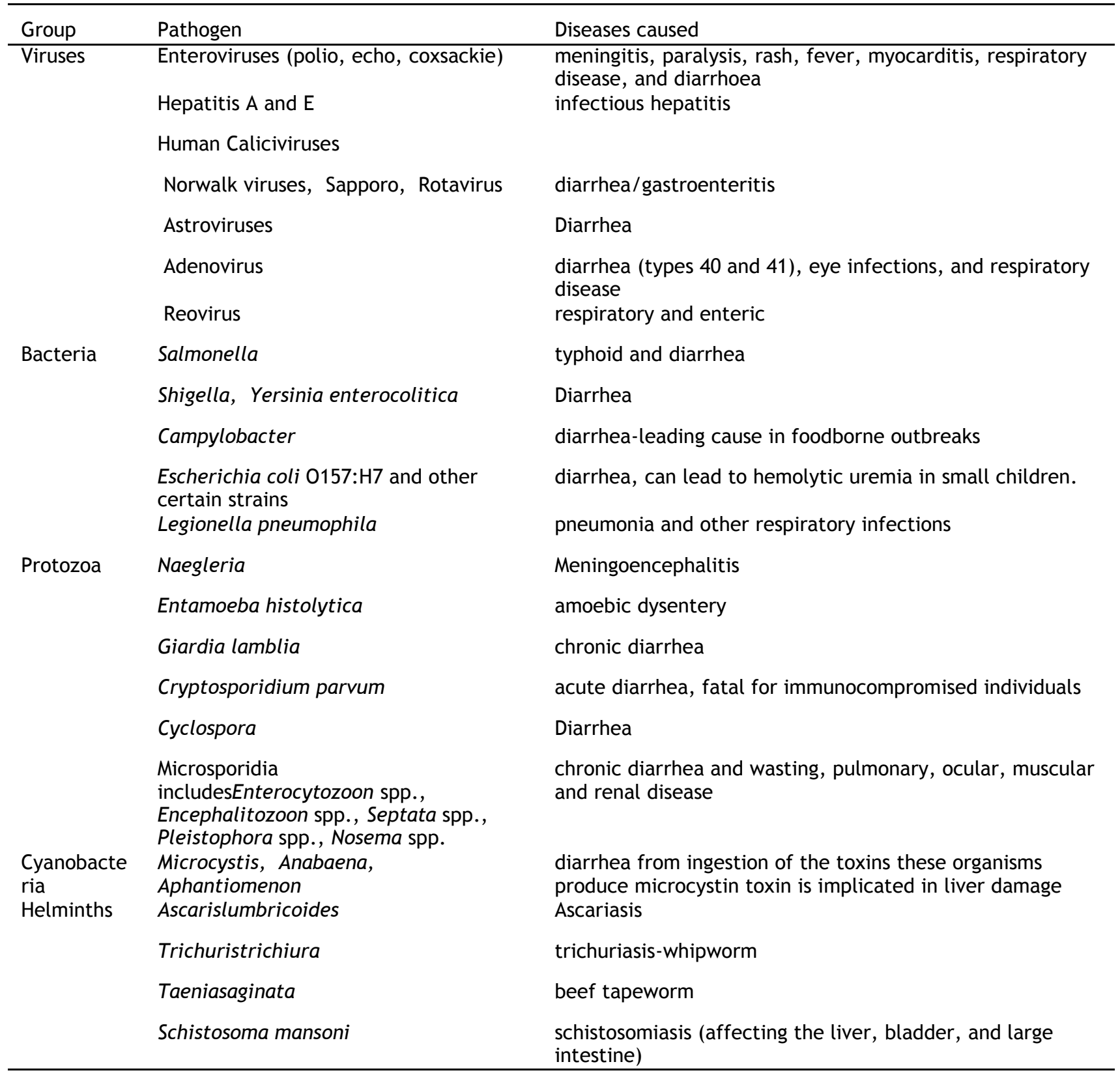

\section{Mode of transmission of pathogen causing waterborne diseases}

Most common mode of transmission is via faecal-oral route whereby contaminated water is ingested. There is a possibility of food contamination as human beings depend on agriculture or aquaculture in quest of food which could be polluted by waste water with excreta. ${ }^{10}$ The use of contaminated water in household and even swimming in it would be the possible cause of waterborne diseases. ${ }^{11}$ Figure 1 showed how organisms found in faecal matter can be transmitted to human.

\section{Prevention of waterborne diseases}

1.Personal hygiene:

Personal hygiene is the utmost important precautionary measure to be taken in order to avoid waterborne diseases. Essential preventive outbreaks include adequate bathing, hand washing and changing into clean clothes to control the spread of pathogen. ${ }^{12}$

2.Ensuring safe water supply:

A safe water supply for the daily needs such as cooking, cleaning, washing food/vegetables and many more is essential. The sources of water supply should be protected by well-constructed design of latrine, septic tanks as well as by avoiding in contact of animals to household water sources. ${ }^{10}$

3.Drinking water should be pure:

Drinking water must be purified properly by means of boiling, filtration or using disinfectants. A sanitary monitoring may be an imperative feature to reduce the chances of getting infected by waterborne pathogens. 


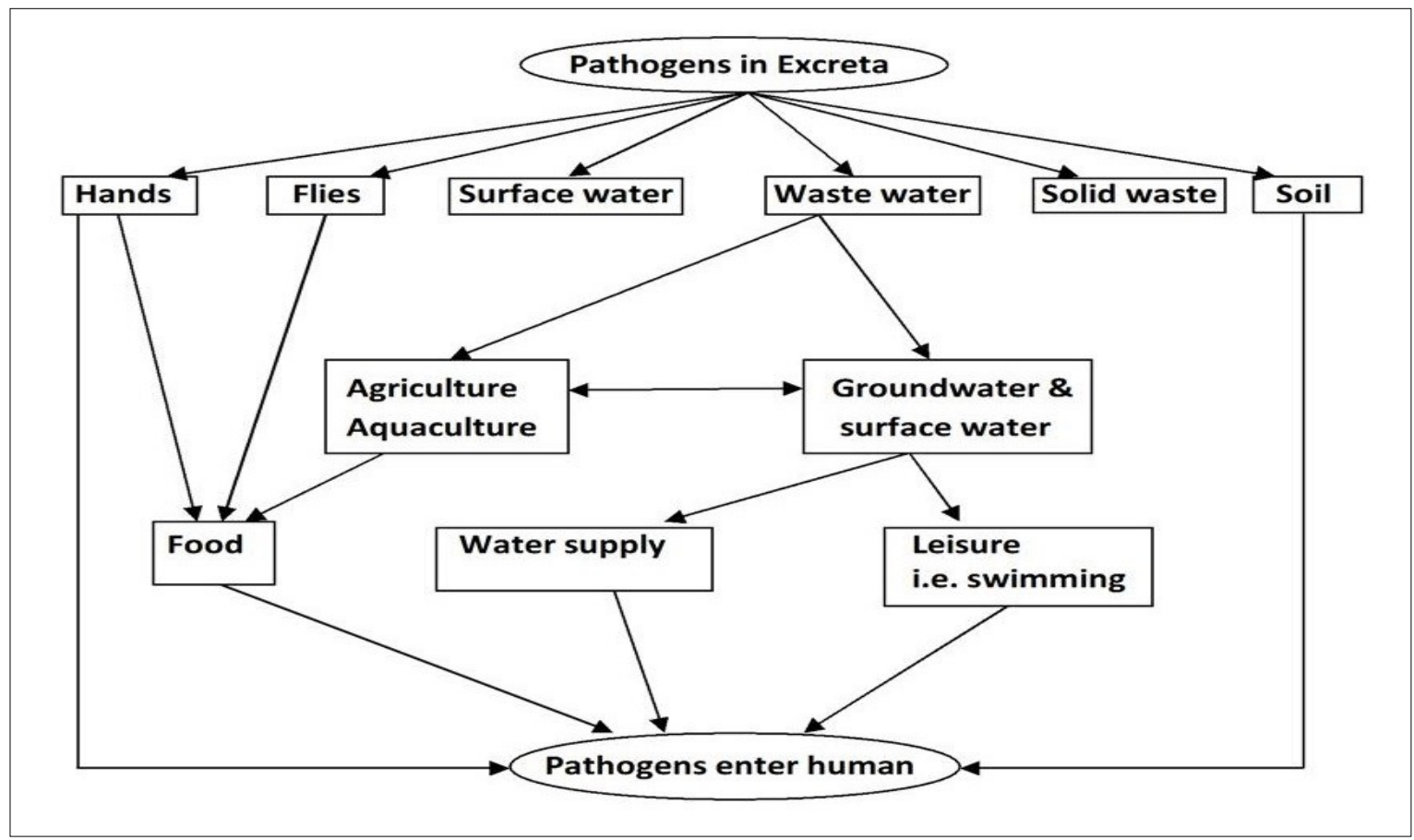

Figure 1: Mechanism of transmission of waterborne pathogens. ${ }^{9}$

\section{Islamic Approaches to Maintain Personal Hygiene to Control Waterborne Diseases}

Poor personal hygiene is the major reason to be infected by waterborne contaminants. ${ }^{15}$ It is mandatory for all Muslims to enjoy the highest standard of personal hygiene. ${ }^{14}$ In Islam, cleanliness and purification are considered as part of the Muslim Holy Faith, A Hadith from Sahih Muslim said, "Cleanliness is half of Deen", (Sahih Muslim, Book 2, No. 432). Almighty Allah says in the Holy Quran regarding purification in Surah Tauba in Holy Quran:

"In it (mosque) are men who love to be purified; and Allah loves those who make themselves pure." (Al Quran, 9:108).

The fundamental forms of personal hygiene in Islam are Gusl and Wudu. Gusl is when all parts of the body including mouth and nose are washed with clean water while in Wudu is when certain body parts are washed. In another verse of Holy Quran, Allah says:

O you who believe! When you intend to offer prayer, wash your faces and your hands (forearms) up to the elbows, rub (by passing wet hands over) your heads, and (wash) your feet up to ankles. If you are in a state of Janaba (i.e. post sexual relations), purify yourself (bathe your whole body). (Al Quran, 5:6)

Indeed a significant numbers of Hadiths of Prophet Muhammad (PBUH) clearly indicate the need of cleanliness:

Abu Hurayrah (may Allah be pleased with him) narrates from the Messenger of Allah (PBUH) said that, 'It is the duty of every Muslim to take a bath (at least) once every seven days, and to wash his head and body. ${ }^{13}$

The followings are Hadiths related to cleanliness and purification from Book of Purification of Sunan Abu Dawud. ${ }^{14}$

Abu al-Tayyah reported a man him that when Abdullah ibn Abbas came to AlBasrah, he would narrate on the authority of Abu Musa. So once he wrote to Abu Musa asking him about the certain matters. Abu replied: One day I was with the Messenger of Allah, and he wished to urinate. So he went to soft ground beneath a wall and urinated. He (the Prophet) then said: If any of you needs to urinate, let him choose an appropriate place for his urination. (Chapter 2, Number 03). ${ }^{15}$

Abu Hurairah said that Prophet (PBUH) said: Be on your guard against two things which provoke cursing. They (the hearers) said: Prophet of Allah, what are these things which provoke cursing? He said: Easing in thoroughfares (where people walk) or under the shade (of the trees) (where they take shelter and rest). (Chapter 14, Number 25).

Narrated Abdullah ibn Mughaffal: The Apostle of Allah (PBUH) said: No one of 
you should make water in his bath and then wash himself there (after urination).(Chapter 15, Number 27). Narrated Abu al-Malih:The Prophet (PBUH) said: Allah does not accept charity from goods acquired by embezzlement as He does not accept prayer without purification. (Chapter 31, Number 59).

Narrated Abu Hurairah:The Prophet (PBUH) said: The purification of the utensil belonging to any one of you, after it has been licked by a dog, consists of washing it seven times, using sand in the first instance. (Chapter, Number 71). Narrated Umm Salamah, Ummul Mu'minin: The slave-mother of Ibrahim ibn Abdur Rahman ibn Awf asked Umm Salamah, the wife of the Prophet (PBUH): I am a woman having a long border of cloth and I walk in filthy place; (then what should I do?). Umm Salamah replied: The Apostle of Allah (PBUH) said: What comes after it cleanses it. (Chapter 142, Number 383).

\section{Control of Waterborne Diseases through Islamic Approaches}

Islam is a religion that reflects a complete code of conduct on life. Control of waterborne diseases by ensuring good personal hygiene and sanitation is within the code of conduct in Islam. Allah has blessed us with water and it is our responsibility to utilize it wisely and keep it clean. Sadly water pollution does happen and man played a role in it. ${ }^{15}$ A large portion of the global population does not have access to clean drinking water and clean water for household use. ${ }^{16}$ However if the Islamic practices are adhered to, we should be able to maintain clean and fresh water that will save us from fatal waterborne diseases.

Prophet Muhammad (PBUH) made his followers aware of the dangerous consequences of using water contaminated with human waste. Thus he made it forbidden to urinate or defecate near to the water source (Sahih Muslim) and he disliked to use toilet area where people take rest, clean themselves and collect water. ${ }^{14}$ Today's science has justified those tasks necessary for maintaining hygiene as well as to control waterborne diseases.

The divine command of Quran from Allah also denotes not to do harm upon the earth after He has set in order, which is an order keeping environment nice and natural. According to Quran:

"To the Madyan people We sent Shu'aib, one of their own brethren: he said: "O my people! Worship Allah; Ye have no other god but Him. Now hath come unto you a clear (Sign) from your Lord! Give just measure and weight, nor withhold from the people the things that are their due; and do no mischief on the earth after it has been set in order: that will be best for you, if ye have Faith" (Al Quran, 7:85)

Allah criticizes those who spread corruption and destroy livestock and crops. In Al Quran Allah Says:

"When he turns his back, His aim everywhere is to spread mischief through the earth and destroy crops and cattle. But Allah loveth not mischief" (Al Quran, 2:205)

Muslims are ordered to keep the water free of impurities and pollution, and make use of clean water. The particular chapter of taharah begins with the categorization of water and describes how the way the water gets impure. ${ }^{13}$

\section{CONCLUSION}

Human beings are the vicegerents of Allah and in Islam they are recognized as the custodians of the earth. We are provided with the things we need and it is our duty to follow the proper regulations of utilizing it. Water is one resource which can save life but become cause of death by getting infected if it is not protected in proper approaches. The Quranic verses and Prophet's tradition (Sunnah) plead us to be attentive of our responsibilities by which we can keep our water sources clean and keep ourselves free of waterborne diseases.

\section{REFERENCES}

1. Colford JM Jr, Roy S, Beach MJ, Hightower A, Shaw SE, Wade TJ. A review of household drinking water intervention trials and an approach to the estimation of endemic waterborne gastroenteritis in the United States. J Water Health. 2006;4:71-88.

2. Messner M, Shaw S, Regli S, Rotert K, Blank V, Soller J. An approach for developing a national estimate of waterborne disease due to drinking water and a national estimate model application. J Water Health. 2006;4:201-40.

3. Fewtrell L, Bartram J. Water quality: guidelines, standards and health: assessment of risk and risk management for water-related infectious disease. 2001.

4. Patz JA, Olson SH, Uejio CK, Gibbs HK. Disease emergence from global climate and land use change. Med Clin North Am. 2008;92:1473-91.

5. Koroglu M, Yakupogullari Y, Otlu B, Ozturk S, Ozden M, Ozer A, Sener K, Durmaz R. A waterborne outbreak of epidemic diarrhea due to group A rotavirus in Malatya, Turkey. New Microbiol. 2011;34:17-24.

6. Bush KF, Luber G, Kotha SR, Dhaliwal RS, Kapil V, Pascual M, Brown DG, Frumkin H, Dhiman RC, Hess J, Wilson ML, Balakrishnan K, Eisenberg J, Kaur T, Rood R, Batterman S, Joseph A, Gronlund CJ, Agrawal A, Hu H. Impacts of climate change on public health in India: future research directions. Environ Health Perspect. 
2011;119:765-70.

7. Baldursson S, Karanis P. Waterborne transmission of protozoan parasites: review of worldwide outbreaks - an update 2004-2010.

Water Res. 2011;45:6603-14.

8. Grabow WOK. Waterborne diseases: update on water quality assessment and control. Water $\mathrm{S}$ A. 1996;22:193-202.

9. Straub TM, Chandler DP. Towards a unified system for detecting waterborne pathogens. J Microbiol Methods. 2003;53:185-97.

10. Demena M, Workie A, Tadesse E, Mohammed S, Gebru T. Waterborne Disease. 2003

11. Michele $\mathrm{CH}$, Virginia AR, Amy MK, Elizabeth $\mathrm{DH}$, Timothy JW, Lorraine CB, Jonathan SY. Recreational water-associated disease outbreaks--United States, 2009-2010. MMWR Morb Mortal Wkly Rep. 2014;63:6-10.

12. Kouadio IK, Aljunid S, Kamigaki T, Hammad K, Oshitani $\mathrm{H}$. Infectious diseases following natural disasters: prevention and control measures. Expert Rev Anti Infect Ther. 2012;10:95-104.

13. Ali MM. Manual of hadith. Routledge. 2013; 401 433.

14. Dawud A Sunan Abu Dawud Sh Muhammad Ashraf. 1984.

15. Qasmi MK. 2014. Concept of cleanliness in Islam. 2014. http://www.deoband.net/blogs/concept-ofcleanliness-in-islam. Accessed July 30, 2016.

16. WHO (1993) Guidelines for Drinking-water Quality. Volume 1: Recommendations. Second edition. World Health Organization, Geneva.

17. WHO (1996) Guidelines for Drinking-water Quality. Volume 2: Health Criteria and Other Supporting Information Second edition, World Health Organization, Geneva.

18. Woodall CJ. Waterborne disease-What are the primary killers? Desalination. 2009;248(1-3): 616 $-621$ 
